\title{
STRATEGI PELAYANAN TRANSPORTASI ONLINE GOJEK DI KOTA KENDARI
}

\author{
Jacob Breemer ${ }^{1)}$ \\ ${ }^{1}$ Jurusan Manajemen Pemasaran dan Perbankan, Politeknik Indotec Kendari
}

\begin{abstract}
Abstrak
Penelitian ini dilakukan pada komunitas transportasi online GOJEK di Kota Kendari dengan rumusan masalah adalah Bagaimana strategi pelayanan transportasi online Gojek. Tujuan penelitian ini adalah untuk mengetahuistrategi pelayanan transportasi online Gojekdi Kota Kendari. Data yang digunakan dalam penulisan tugas akhir ini dikumpulkan melalui observasi, wawancara, dan dokumentasi dan dianalisis dengan metode deskripsi kualitatif. Hasil penelitian ini diperoleh kesimpulan bahwa strategi pelayanan transportasi online gojek di Kota Kendari dengan mengutamakan kualitas jasa, mengelola harapa pelanggan, membutikan pelayanan kepada pelanggan, memberikan informasil jasa online gojek kepada pelanggan dan membangun budaya layam transportasi online yang dibutuhkan oleh masyarakat. Strategi pelayanan transportasi mendukung kelancaran pelayanan pelanggan dengan jasa internet yang didalamnya terdapat bukti layanan yang baik, perhatian kepada pelanggan, dapat dihandalkan, respon dengan baik kepada pelanggan dan meberi jaminan keselamatan kepada pelanggan yang pada akhirnya akan meningkatkan kepercayaan dan kepuasan masyarakat terhadap transportasi online gojek
\end{abstract}

Kata kunci : Pelayanan Transportasi

\begin{abstract}
This research was conducted at the GOJEK online transportation community in Kendari City with the formulation of the problem is What is the Gojek online transportation service strategy. The purpose of this study was to determine the Gojek online transportation service strategy in Kendari City. The data used in the writing of this final project were collected through observation, interviews, and documentation and analyzed by qualitative description methods. The results of this study concluded that the online gojek transportation service strategy in the city of Kendari by prioritizing service quality, managing customer expectations, membutikan service to customers, providing information on online gojek services to customers and building a culture of online transportation service needed by the community. The transportation service strategy supports the smooth running of customer service with internet services in which there is evidence of good service, attention to customers, can be relied on, responds well to customers and guarantees safety to customers which will ultimately increase public trust and satisfaction with online transportation.
\end{abstract}

Keywords: Transportation Services 


\section{PENDAHULUAN}

\subsection{Latar Belakang}

Strategi pelayanan transportasi online terbatas para masyarakat pengguna smartphone dapat dilakukan dengan emphaty, reliabilitu, reasponsiveness, dan assurance. (TERRA). Layanan transportasi online membutuhkan bukti fisik, perhatian, kehandalan, daya tanggap dan jaminan. Berdasarkan hal tersebut maka dapat dilihat bahwa anggota gojek di Kota Kendari membutuhkan strategi pelayanan yang tepat atau membuat formulasi strategi yang dapat mendukung aktivitas mereka dan mengatasi keterbatasan yang mereka miliki.

Kelompok Gojek di Kota Kendari mencapai 168 orang dari berbagai kalangan, baik masyarakat umum, pelajar, karyawan maupun pegawai negeri yang ikut dalam aktivitas gojek. Namun demikian para anggota Gojek harus mendapat izin aplikasi dari pemilik Gojek dan terdaftar pada lokasi-lokasi atau outlate yang dibentuk di Kota Kendari. Hasil observasi diperoleh bahwa di Kelompok Gojek tersebar di Kecamatan Mandonga, Baruga, Poasia,Wua-Wua dan Kendari Barat, Kendari dan Kandai.Sektor pembagian wilayah ini dikoordinasikan oleh para pengelola akun Gojek. Wilayah operasi Gojek di Kota Kendari tidak terbatas untuk melayani penumpang yang menggunakan jasa Gojek.

Pelayanan transportasi online ini tidak selamanya berlangsung dengan baik karena kekuatan, kelemaha, peluang dan ancaman yang terkadang mempengaruhi palayanan sehingga para pelaku bisnis gojek harus lebih menerpakan strategi pelayanan dengan formula yang baik seperti membuat rencana kerja, menetapkan lokasi kerja, melayani dengan ramah, memberikan rasa aman kepada konsumen dan menjaga keselamatan konsumen. Strategi ini tidak mudah dilakukan karena tidak semua anggota gojek memiliki pemikiran yang sama dalam bekerja. Dalam hasil observasi, tidak semua pengemudi gojek memiliki kendaraan sendiri selain itu pelayanan yang diberikan tidak tetap karena kesibukan pada pekerjaan lain. Hal seperti menggunakan kualitas layanan seperti yang dikembangkan oleh Zeithaml (1998) untuk melaksanakan pelayanan kepada konsumen secara berkualitas dengan menggunakan unsur tangible, ini kemudian berdampak kepada pelayanan dan penghasilan sehingga diperlukan adanya strategi untuk meningkatkan aktivitas transportasi online dalam rangka melayani konsumen di Kota Kendari.

\subsection{Tinjauan Pustaka}

\subsubsection{Konsep Pemasaran}

Pemasaran adalah salah satu kegiatan-kegiatan pokok dalam suatu perusahaan untuk mempertahankan hidup dan untuk mendapatkan laba/keuntungan. Kegiatan pemasaran dalam perusahaan harus dapat memberikan kepuasan kepada konsumen agar perusahaan tetap bisa berkembang, atau konsumen mempunyai pandangan baik terhadap perusahaan tersebut. Pengertian pemasaran menurut Kotler dan Armstrong (2008: 6)," merupakan proses di mana perusahaan menciptakan nilai bagi 
pelanggan dan membangun hubungan yang kuat dengan pelanggan dengan tujuan untuk menangkap nilai dari pelanggan sebagai imbalannya".

Pemasaran secara sederhana adalah yang mengatur relasi menguntungkan dengan konsumen. Tujuan dari pemasaran adalah menciptakan nilai untuk konsumen dan untuk menangkap nilai dari konsumen atau mendapat timbal balik dari konsumen. Tidak hanya organisasi profit yang memerlukan pemasaran tetapi organisasi non-profit juga memerlukan pemasaran guna meningkatkan pemasukan dan upaya yang akan dicapai. Terdapat 2 pengertian pemasaran menurut Kotler dan Armstrong (2008:12) dari sudut pandang sosial dan manajer pemasaran :

1) Sudut pandang sosial

Pemasaran adalah proses untuk bersosialisasi yang dimana individuindividu dan kelompok-kelompok mendapatkan apa yang mereka butuhkan dan inginkan melalui penciptaan, permintaan, dan kebebasan dalam menukar nilai produk dan jasa dengan yang lain.

2) Sudut pandang manajer pemasaran

Seni untuk menjual produk dimana pemasaran mengetahui dan mengerti konsumen dengan baik sehingga produk atau pelayanan yang diciptakan tepat untuk konsumen dan terjual dengan sendirinya

Konsep pemasaran juga mengalami perubahan. Lima konsep dasar pemasaran menurut Kotler dan Keller (2009: 16) :

1). Konsep Produksi

Konsep produksi adalah konsep pertama didunia bisnis. Dimana konsumen-konsumen akan memilih produk yang tersedia dan tidak mahal. Manajer produksi berorientasi pada pencapaian efisiensi produk, biaya rendah dan distribusi.

2). Konsep Produk

Konsep produk dimana konsumen akan meminta produk yang paling berkualitas, memiliki peforma atau fitur yang inovatif. Manajer yang fokus pada konsep ini membuat produk yang superior dan terus di tingkatkan dari waktu ke waktu. Produk yang baru atau produk yang baru ditingkatkan belum tentu sukses tanpa penetapan biaya, distribusi, pengiklanan dan penjualan yang tepat.

3). Konsep Penjualan

Konsep penjualan menetapkan penjualan yang agresif dengan upaya promosi, dimana jika tidak diterapkan maka produk tidak akan terjual secara memuaskan

4). Konsep Pemasaran

Falsafah pemasaran yang berkeyakinan bahwa pencapaian sasaran organisasi tergantung pada penentuan kebutuhan dan keinginan pasar sasaran dan penyampaian kepuasan lebih efektif dan efisien daripada pesaing.

5). Konsep Pemasaran Sosial

Konsep penjualan menetapkan penjualan yang agresif dengan upaya promosi, dimana jika tidak diterapkan maka produk tidak akan terjual secara memuaskan.

Definisi yang paling luas yang dapat menerangkan secara jelas arti pentingnya pemasaran dikemukakan oleh Stanton, William J. dalam Swastha 
(2000:4) Pemasaran adalah suatu sistem keseluruhan dari kegiatan-kegiatan bisnis yang ditujukan untuk merencanakan, menentukan harga, mempromosikan dan mendistribusikan barang dan jasa yang memuaskan kebutuhan baik kepada pembeli yang ada maupun pembeli potensial.

\subsubsection{Konsep Strategi Pelayanan}

\subsubsection{Pengertian Strategi}

Strategi merupakan alat untuk mencapai tujuan dan dalam perkembangannya konsep mengenai strategi terus berkembang. Hal ini dapat ditujukkan oleh adanya perbedaan konsep mengenai strategi selama 30 tahun terakhir. Menurut Porter strategi adalah suatu alat yang sangat penting untuk mencapai keunggulan bersaing (Rangkuti, 2004: 4). Senada dengan itu, Hamel dan Pharalad juga mengatakan strategi merupakan tindakan yang bersifat incremental (senantiasa meningkat) dan terus-menerus, dilakukan berdasarkan sudut pandang tentang apa yang diharapkan oleh pelanggan di masa depan (Rangkuti, 2004:4).

Menurut David (2011:18-19) Strategi adalah sarana bersama dengan tujuan jangka panjang yang hendak dicapai. Menurut Tjiptono (2006:3) istilah strategi berasal dari bahasa Yunani yaitu strategia yang artinya seni atau ilmu untuk menjadi seorang jendral. Strategi juga bisa diartikan suatu rencana untuk pembagian dan penggunaan kekuatan militer pada daerah - daerah tertentu untuk mencapai tujuan tertentu. Sedangkan Menurut Menurut Pearce II dan Robinson (2008:2), strategi adalah rencana berskala besar, dengan orientasi masa depan, guna berinteraksi dengan kondisi persaingan untuk mencapai tujuan

Perusahaan dari definisi tersebut, dapat di simpulkan bahwa pengertian dari Strategi adalah sebuah tindakan proses perencanaan untuk mencapai tujuan yang telah di tetapkan, dengan melalukan hal- hal yang besifat terus menerus sesuai keputusan bersama dan berdasarkan sudut pandang kebutuhan pelanggan. Rangkuti (2013:183) berpendapat bahwa strategi adalah perencanaan induk yang komprehensif, yang menjelaskan bagaimana perusahaan akan mencapai semua tujuan yang telah di tetapkan berdasarkan misi yang telah di tetapkan sebelumnya. Menurut Stoner, Freeman, dan Gilbert. Jr (2005), konsep strategi dapat di definisikan berdasarkan dua perspektif yang berbeda yaitu: (1) dari perspektif apa suatu organisasi ingin dilakukan (intens to do), dan (2) dari perspektif apa yang organisasi akhirnya lakukan (eventually does). Dari definisi tersebut penulis menyimpulkan bahwa pengertian strategi adalah hal hal yang perusahaan ingin lakukan untuk mencapai suatu tujuan yang telah di tetapkan sebelumnya. 


\subsubsection{Pelayanan}

Pelayanan menurut Kamus Besar Bahasa Indonesia (KBBI) adalah sebagai suatu usaha untuk membantu menyiapkan atau mengurus apa yang diperlukan orang lain. Sedangkan menurut Moenir (2010: 26) pelayanan adalah kegiatan yang dilakukan oleh seseorang atau sekelompok orang dengan landasan faktor materi melalui sistem, prosedur dan metode tertentu dalam rangka usaha memenuhi kepentingan orang lain sesuai dengan haknya.

Sedangkan menurut Groonros dalam Ratminto dan Atik (2005:2) pelayanan adalah suatu aktivitas atau serangkaian aktivitas yang bersifat tidak kasat mata (tidak dapat diraba) yang terjadi sebagai akibat adanya interaksi antara konsumen dengan karyawan atau hal-hal lain yang di sediakan oleh perusahaan pemberi pelayanan yang dimaksudkan untuk memecahkan permasalahan konsumen atau pelanggan.

Berbeda dengan Supranto (2006:227) mengatakan bahwa pelayanan atau jasa merupakan suatu kinerja penampilan, tidak terwujud dan cepat hilang, lebih dapat dirasakan dari pada dimiliki, serta pelanggan lebih dapat berpartisipasi aktif dalam proses mengonsumsi jasa tersebut. Menurut Philip Kotler dalam Supranto (2006:228) karakteristik jasa dapat diuraikan sebagai berikut:

1). Intangible (tidak terwujud) Suatu jasa memiliki sifat tidak berwujud, tidak dapat dirasakan dan dinikmati sebelum dibeli oleh konsumen.

2). Inseparibility (tidak dapat dipisahkan) Pada umumnya jasa yang diproduksi (dihasilkan) dan dirasakan pada waktu bersamaan dan apabila dikehendaki oleh seseorang untuk diserakan kepada pihak lainnya, maka dia akan tetap merupakan bagian dari jasa tersebut.

3). Variability (bervariasi) Jasa senantiasa mengalami perubahan, tergantung dari siapa penyedia jasa, penerima jasa dan kondisi dimana jasa tersebut diberikan.

4). Perishability (tidak tahan lama) Daya tahan suatu jasa tergantung suatu situasi yang diciptakan oleh berbagai faktor.

\subsubsection{Strategi Pelayanan}

Strategi pelayanan adalah cara bagaimana menyikapi suatu keadaan dan kenyataan dengan memberikan solusi untuk mampu keluar dari keadaan tersebut. Banyak faktor yang perlu dipertimbangkan dalam meningkatkan strategi pelayanan, diantaranya adalah:

1). Mengidentifikasi misi layanan/jasa

Artinya perlu berupaya memberikan kualitas pelayanan yang terbaik dan pernyataan misi harus mencerminkan komitmen organisasi kerja. Oleh karena itu, langkah pertama yang harus dilakukan adalah mengadakan riset pelayanan masyarakat 
sasaran.

2). Mengelola harapan konsumen.

Tidak jarang suatu lembaga kesehatan berusaha melebihlebihkan pesan komunikasinya kepada konsumen dengan maksud supaya mereka terpikat.

3). Mendidik konsumen tentang pelayanan

Membantu konsumen dalam memahami suatu pelayanan merupakan upaya yang sangat positif dalam rangka menyampaikan kualitas pelayanan.

4). Mengelola bukti kualitas jasa

Pengelolaan bukti kualitas jasa bertujuan untuk memperkuat persepsi konsumen selama dan sesudah pelayanan diberikan. Oleh karena itu, pelayanan merupakan kinerja dan tidak dapat dirasakan sebagaimana halnya barang, maka pasien memperhatikan bukti langsung yang berkaitan dengan pelayanan sebagai bukti kualitas.

5). Mengembangkan budaya kualitas

Budaya kualitas merupakan sistem nilai yang menghasilkan lingkungan yang kondusif bagi organisasi kerja dan menyempurnakan kualitas secara terus-menerus.

6). Menindaklanjuti pelayanan dalam rangka menyempurnakan atau memperbaiki aspek-aspek pelayanan yang memuaskan dan mempertahankan aspek-aspek yang sudah berjalan.

\subsubsection{Konsep Media Online Dan Transportasi Online}

\subsubsection{Pengertian Media Online}

Saverin dan Tankard (2008: 443) menjelaskan bahwa media adalah segala sesuatu yang dapat menyalurkan informasi dari sumber informasi kepada peneriman informasi, dan yang dimaksud dengan baru adalah sesuatu yang dapat menciptakan suatu inovasi ataupun perubahan yang dapat melahirkan sesuatu yang sangat diinginkan seseorang. New media atau media baru adalah sebuah terminologi untuk menjelaskan konvergensi antara teknologi komunikasi digital yang terkomputerisasi serta terhubung ke dalam jaringan. Termasuk dalam new media atau media baru adalah internet, selain internet tidak termasuk ke dalam new media, seperti media cetak, televisi, majalah, Koran, dan lain-lain. New media juga bisa diartikan sebagai produk teknologi komunikasi di media massa yang akan datang bersama-sama dengan komputer digital.

Internet adalah jaringan komuputer dunia yang mengembangkan ARPANET (Advanced Research Project Agency Network), suatu sistem komunikasi yang terkait dengan pertahanan keamanan yang dikembangkan pada tahun 1960-an. Manfaat sistem komunikasi yang berjaringan ini dengan cepat ditangkap oleh para peneliti dan pendidik secara umum. Akhir-akhir ini, melalui komputer dirumah, modem, dan warnet, serta melalui layananlayanan seperti Web- TV, Internet hadir untuk publik. Pada keadaan 
seperti ini pun masih ada beberapa orang yang tak setuju bahwa internet merupakan sebuah media massa baru. Internet berkembang secara fenomenal, baik dari segi jumlah host computer (komputer induk) maupun dari segi jumlah penggunanya, selama beberapa tahun terakhir (Saverin dan Tankard, 2008: 443).

Levy menggambarkan (Severin \& Tankard, 2008: 6) internet sebagai "saluran komunikasi yang tidak terbatas, pembangunan komunikasi, iklan elektronik dan interaksi yang sangat kompleks yang mengaburkan batas antara penyedia dan konsumen". Seperti yang dijelaskan oleh Saverin dan Tankard (2008: 8-9) banyak pengguna layanan internet yang juga menyadari bahwa mereka juga perlu berhati-hati terhadap informasi yang mereka terima.

\subsubsection{Transportasi Online}

Pengertian transportasi menurut Morlok (1978) adalah kegiatan memindahkan atau mengangkut sesuatu dari satu tempat ketempat lain. Menurut Bowersox (1981), transportasi adalah perpindahan barang atau penunpang dari satu tempat ketempat lain, dimana produk dipindahkan ke tempat lain, dimana produk dipindahkan ke tempat tujuan dibutuhkan. Menurut Steenbrink (1974), transportasi didefinisikan sebagai perpindahan orang dan atau barabg dengan menggunakan kendaraan ataualat lain dari dan ketempat-tempat yang terpisah secara geografis.

Kegiatan transportasi bukan merupakan suatu tujuan melainkan mekanisme untuk mencapai tujuan. Menurut Setijowarno dan Frazila (2001), pergerakan orang dan barang dari satu tempat ke tempat yang lainnya mengikuti tiga kondisi yaitu :

1). Perlengkapan, relative menarik antara dua atau lebih tujuan

2). Keinginan untuk mengatasi jarak, dimana sebagai perpindahan yang diukur dalam kerangka waktudan ruangyang dibutuhkan untuk mengatasi jarak dan teknologi terbaik untuk mencapainya.

3). Kesempatan intervensi berkompetisi di antara beberapa lokasi untuk memenuhi kebutuhan dan penyediaan.

Masing-masing moda transportasi menurut Setijowarno dan Frazila (2 001), memiliki ciri-ciri operasional yang berlainan yakni dalam hal :

1). Kecepatan, menunjukkan berapa lama waktu yang dibutuhkan untuk bergerak antara dua lokasi

2). Tersediannya pelayanan (availability of services), menyangkut kemampuan untuk menyelenggarakan hubungan antara dua lokasi.

3). Pengoperasian yang diandalkan (dependability of operations), menunjukkan perbedaan-perbedaan yang terjadi antara kenyataan dan jadwal yang ditentukan.

4). Kemampuan (capability), merupakan kemampuan untuk dapat menangani segala bentuk dan keperluan akan angkutan.

5). Frekuensi adalah banyaknya hubungan yang dijadwalkan. 


\section{METODE PELAKSANAAN}

\subsection{Waktu dan Tempat}

Penelitian ini dilakukan sejak Bulan Mei - Juni 2019. Penelitian ini dilakukan pada Kantor Gojek Kota Kendari yang beralamat di J1 MT. Haryono No, 36 Kendari.

\subsection{Pengumpulan Data}

1) Observasi

Dalam penelitian ini data dikumpul dengan metode sebagai berikut :

Observasi dalam penelitian ini merupakan bentuk pengumpulan data dengan teknik pengamatan langsung ke objek penelitian tentang hal-hal yang berkaitan dengan tujuan penelitian

2) Wawancara

Wawancara adalah bentuk pengumpulan data secara kualitatif untuk memperoleh data tambahan dalam penelitian ini, maka dilakukan wawancara dengan pimpinan Gojek Kota Kendari.

3) Dokumentasi

Dokumentasi yaitu metode pengumpulan data yang dilakukan dengan mengumpulkan data-data yang telah didokumentasi seperti laporan kegiatan anggota Gojek di Kota Kendari.

\section{HASIL DAN PEMBAHASAN}

Jasa memiliki banyak arti yaitu pelayanan pribadi sampai jasa sebagai suatu produk. Produksi jasa mungkin berkaitan dengan produk fisik atau tidak. Jasa dalam tulisan ini adalah Go-jek yang bergerak dibidang jasa transportasi yang beroperasi di Kota Kendari. Secara umum Go-Jek Indonesia adalah suatu jasa transportasi yang ada di Jakarta yang beroperasi sejak tahun 2011. Go-Jek merupakan pionir penyedia jasa layanan ojek profesional.

Di Kota Kendari gojek berusaha menawarkan faktor kecepatan, keamanan, dan kenyamanan bagi para pelanggannya, Go-Jek tumbuh sebagai startup yang menjanjikan di Kota Kendari. Untuk mengurangi permasalahan penyediaan uang tunai, Go-Jek menawarkan solusi e-wallet Go- Jek Credit. Bisa dibilang Go-Jek laksana Uber versi ojek yang cocok dimanfaatkan untuk mengantarkan barang, sarana transportasi, dan bahkan membantu kegiatan berbelanja di Kota Kendari.

Dalam meningkatkan kualitas jasa, banyak faktor yang perlu dipertimbangkan dan upaya tersebut juga berdampak luas terhadap budaya organisasi secara keseluruhan. Faktor- faktor yang perlu mendapat perhatian dalam pelayanan transportasi online yaitu: 1). Mengidentifikasi determinan (faktor yang menentukan) utama kualitas jasa.

Setiap perusahaan jasa perlu berupaya memberikan kualitas yang terbaik kepada pelanggannya.Untuk itu dibutuhkan identifikasi determinan utama kualitas jasa dari sudut pandang pelanggan.Oleh karena itu langkah pertama yang dilakukan adalah melakukan riset untuk mengidentifikasi determinan jasa yang paling penting bagi pasar sasaran.Langkah berikutnya adalah memperkirakan penilaian yang diberikan pasar sasaran terhadap perusahaan dan pesaing berdasarkan 
determinandeterminan tersebut. Dengan demikian dapat diketahui posisi relatif perusahaan di mata pelanggan dibandingkan para pesaing, sehingga perusahaan dapat memfokuskan upaya peningkatan kualitasnya pada determinan - determinan tersebut. Namun perusahaan perlu memantau setiap determinan sepanjang waktu, karena sangat mungkin prioritas pasar mengalami perubahan.

2). Mengelola harapan pelanggan jasa transportasi online.

Tidak jarang suatu perusahaan berusaha melebih - lebihkan pesan komunikasinya kepada pelanggan dengan maksud agar mereka terpikat. Hal seperti ini dapat menjadi 'bumerang (perbuatan yang dapat merugikan pelakunya)' bagi perusahaan. Semakin banyak janji yang diberikan, maka semakin besar pula harapan pelanggan (bahkan bisa menjurus menjadi tidak realistis) yang pada gilirannya akan menambah peluang tidak dapat terpenuhinya harapan pelanggan oleh perusahaan. Untuk itu ada satu hal yang dapat dijaclikan pedoman, yaitu "Jangan janjikan apa yang tidak bisa diberikan, tetapi berikan sesuatu dari yang dijanjikan".

3). Mengelola bukti kualitas jasa yang bertujuan untuk memperkuat persepsi (tanggapan) pelanggan selama dan sesudah jasa diberikan.

Pengelolaan bukti kualitas jasa bertujuan untuk memperkuat persepsi pelanggan selama clan sesudah jasa diberikan.Oleh karena jasa merupakan kinerja dan tidak dapat dirasakan sebagaimana halnya barang, maka pelanggan cenderung memperhatikan fakta-fakta tangibles yang berkaitan dengan jasa sebagai bukti kualitas. Dari sudut pandang perusahaan jasa, bukti kualitas meliputi segala sesuatu yang dipandang konsumen sebagai indikator 'seperti apa jasa yang akan diberikan' (pre-service expectation) dan 'seperti apa jasa yang telah diterima' (post-service evaluation). Bukti- bukti kualitas jasa bisa berupa fasilitas fisik jasa (seperti gedung, kendaraan, dan sebagainya), penampilan pemberi jasa, perlengkapan dan peralatan yang digunakan untuk memberikan jasa, laporan keuangan, dan logo perusahaan. Selain itu berbagai faktor seperti musik, warna, aroma, temperatur, lokasi gedung, tataletak jasa, dan atmosfir (situasi dan kondisi transaksi) dapat pula menciptakan persepsi tertentu terhadap perusahaan jasa, misalnya keramahan, ketenangan, kecermatan, wibawa, rasionalitas, stabilitas, maupun

4). Mendidik konsumen tentang jasa layanan transportasi online

Membantu pelanggan dalam memahami suatu jasa- merupakan upaya yang sangat positif dalam rangka menyampaikan kualitas jasa. Pelanggan yang lebih 'terdidik' akan dapat mengambil keputusan secara lebih baik. Oleh karenanya kepuasan mereka dapat tercipta lebih tinggi. Upaya mendidik konsumen dapat dilakukan dalam bentuk:

a. Perusahaan mendidik pelanggannya untuk melakukan sendiri jasa/ pelayanan tertentu, misalnya mengisi blanko/formulir pendafta ran, mengangkut barang belanjaan sendiri, dan lain-lain,

b. Perusahaan membantu pelanggan mengetahui kapan menggunakan suatu jasa dan memanfaatkan periode biasa (bukan puncak),

c. Perusahaan mendidik pelanggannya mengenai cara menggunakan jasa,

d. Perusahaan dapat pula meningkatkan persepsi terhadap kualitas dengan cara menjelaskan kepada pelanggan alasan-alasan yang mendasari suatu kebijakan 
5). Mengembangkan budaya kualitas layanan transportasi online.

Budaya kualitas merupakan sistem nilai organisasi yang menghasilkan lingkungan yang kondusif bagi pembentukan dan penyempurnaan kualitas secara terus- menerus. Budaya kualitas terdiri dart filosofi, keyakinan, sikap, norma, nilai, tradisi, prosedur, dan harapan yang meningkatkan kualitas. Agar dapat tercipta budaya kualitas yang baik, dibutuhkan komitmen menyeluruh pada seluruh anggota organisasi. Ada beberapa faktor yang dapat memperlancar dan sekaligus dapat pula menghambat pengembangan jasa yang berkualitas, yaitu:

a. Manusia, misalnya deskripsikerja, seleksi, pelatihan, imbalan/gaji, jalur karir.

b. Organisasi/struktur, meliputi integrasi/koordinasi fungsi-fungsi dan struktur pelaporan.

c. Pengukuran, yaitu evaluasi kinerja dan pemantauan keluhan dan kepuasan pelanggan.

d. Pendukung sistem, yakni faktor teknis, komputer, database.

e. Pelayanan, meliputi nilai tambah, rentang dan kualitas, standar kinerja, pemuasan kebutuhan dan harapan.

f. Program, meliputi pengelolaan keluhan, alat-alat penjualan/ promosi, alat-alat manajemen.

g. Komunikasi internal, terdiri atas prosedur dan kebijalcsanaan, umpan balik dalam organisasi.

h. Komunikasi ekstemal, yakni pendidikan pelanggan (customer education), penciptaan harapan, citra (image) perusahaan.

Upaya membentuk budaya kualitas dapat dilakukan pengembangan suatu program yang terkoordinasi yang diawali dari seleksi dan pengembangan driver gojek. Anggota driver gojek merupakan aset utama perusahaan dalam rangka memenuhi kebutuhan dan memuaskan pelanggan. Dalam rantai profit jasa, kualitas jasa internal yang mengarah pada kepuasan anggota driver gojek pada gilirannya akan dapat memberikan profit yang besar pada perusahaan. Ada delapan program pokok yang saling terkait guna membentuk budaya kualitas, yaitu:

a. Pengembangan individual

Perusahaan menyusun manual yang terprogram mengenai instruksi pekerjaan, sehingga anggota driver gojek baru dapat memperoleh keterampilan dan pengetahuan teknis yang dibutuhkan untuk menjalankan bekerja.

b. Pelatihan manajemen

Perusahaan mengikutsertakan manajemennya (termasuk manajer madya dan manajemen lini pertama) dalam program pengembangan manajemen, seperti seminar, simposium, kursus singkat, dan lokakarya.

c. Perencanaan sumberdaya manusia

Perusahaan mengidentifikasi calon- calon potensial untuk menduduki posisi kunci dalam perusahaan untuk periode yang akan datang.

d. Standar kinerja

Perusahaan menyusun suatu pedoman (bisa berupa booklet) yang berisi instruksi dan prosedur melaksanakan suatu tugas, misalnya bagaimana menghadapi calon konsumen, konsumen, atau pelanggan. 
e. Pengembangan karir

Melalui program pengembangan pekerjaan dengan tuntutan keahlian dan tanggung jawab yang semakin besar, diharapkan setiap anggota driver gojek memiliki kesempatan untuk berkembang dalam perusahaan.

f. Survei opini (penelusuran pendapat)

Perusahaan perlu melaksanakan survei pendapat tahunan untuk mendapatkan masukan yang berharga guna melakukan penyempurnaan kualitas dan mencegah timbulnya perilaku yang tidak baik.

g. Perlakuan yang adil

Anggota driver gojek diberi buku pegangan yang berisi harapan dan kewajiban perusahaan terhadap mereka.Buku pegangan tersebut juga berisi ketentuan atau prosedur yang dibutuhkan oleh anggota driver gojek yang membutuhkan bantuan untuk mengatasi suatu masalah atau kesulitan.

h. Profit sharing (pembagian keuntungan/laba)

Adanya rencana pembagian laba dapat mendorong anggota driver gojek untuk lebih bertanggung jawab terhadap kesuksesan perusahaan

\section{SIMPULAN}

Berdasarkan hasil pembahasan yang disajikan sebelumnya, maka dapat disimpulkan bahwa strategi pelayanan transportasi online gojek di Kota Kendari dengan mengutamakan kualitas jasa, mengelola harapan pelanggan, membutikan pelayanan kepada pelanggan, memberikan informasi jasa online gojek kepada pelanggan dan membangun budaya transportasi online yang dibutuhkan oleh masyarakat. Strategi pelayanan transportasi mendukung kelancaran pelayanan pelanggan dengan jasa internet yang didalamnya terdapat bukti layanan yang baik, perhatian kepada pelanggan, dapat dihandalkan, respon dengan baik kepada pelanggan dan memberi jaminan keselamatan kepada pelanggan yang pada akhirnya akan meningkatkan kepercayaan dan kepuasan masyarakat terhadap transportasi online gojek.

\section{DAFTAR PUSTAKA}

Amajida, F. D. (2016). Kreativitas Digital Dalam Masyarakat Risiko Perkotaan: Studi Tentang Ojek Online “GO-JEK” Di Jakarta.Informasi, 46(1), 115- 128

Dagun, S.M. (2006). Kamus Besar Ilmu Pengetahuan. Jakarta: Lembaga Pengkajian Kebudayaan Nusantara (LPKN).

Effendy, O.U. (2007). Ilmu Komunikasi (Teori dan Praktek). Bandung: PT. Remaja Rosdakarya

Kemp \& Dayton. (2003). Planning and Procing Instructional Media (Fifth Edition). New

York: Harper \& Row, Publisher

Kotler dan Armstrong. (2008). Manajemen Pemasaran. Jakarta: Perhanlindo Persana

Kotler dan Keller. (2009). Manajemen Pemasaran. Jakarta: Indeks

Levie, W. H. and Lentz, R. (1982). Effects of text illustrations: a review of research.

Educational Communication and Technology Journal, 30: 195-232

Moenir. (2010). Manajemen Pelayanan Umum Di Indonesia. Jakarta. Bumi Aksara 
Morlok, E.K. (1978). Pengantar Teknik dan Perencanaan. Transportasi. Yogyakarta, UGM Prees.

Rangkuti. (2004). Analisis SWOT: Teknik Membedah Kasus Bisnis. Jakarta: Gramedia Pustaka Utama.

Rangkuti. (2013). Manajemen Strategi. Jakarta: Gramedia Pustaka Utama.

Ratminto dan Atik. (2005). Manajemen Pelayanan, Disertai Dengan Pengembangan Model Konseptual, Penerapan Citizen's Charter Dan Standar Pelayanan Minimal. Yogyakarta: Pustaka Pelajar

Rifusua. (2010). Analisis Faktor-Faktor Yang Mempengaruhi Permintaan Busway Di DKI Jakarta Tahun 2004-2008. Jakarta: Jurnal Universitas Indonesia

Sinambela, L.P. Dkk. (2011). Reformasi Pelayanan Publik. Jakarta: Bumi Aksara Steenbrink. (1974). Pendidikan Islam dalam Kurun Modern, Cet. I. Jakarta: LP3IS

Setijowarno dan Frazila. (2001). Pengantar Sistem Transportasi. Semarang: Universitas Katolik

Supranto. (2006). Manajemen Pemasaran Jasa. Jakarta: Erlangga

Swastha, Basu DH. (2000). Manajemen Pemasaran. Yogyakarta. BPFE-UGM

Tjiptono. (2008). Strategi Pemasaran. Andi: Yogyakarta

Tjiptono. (2006). Manajemen Jasa. Andi: Yogyakarta 